\title{
The 1885 Northwest Resistance: Causes to the Conflict
}

Jesse Thistle

Third Year Paper

Chicago Style Citation

In late spring 1885, Métis and Canadian forces clashed in a series of battles in northern Saskatchewan, collectively known today as the Northwest Resistance. The standard Canadian historiography regarding these confrontations has, over the years, tended to attribute full blame to one man-Louis Riel. A perfect example is Tom Flanagan's Louis 'David' Riel: Prophet of the New World, which portrays Riel as a rabble-rousing firebrand who pits a simple clan of erstwhile 'half-breeds' against the Dominion of Canada to fulfill his divine mission from God and his delusional quest for glory. ${ }^{1}$ By portraying Riel as a manipulator, this historiographical myth simultaneously discredits the Métis cause while painting the Canadian government as justified liberators whose rescue efforts free the young nation from the clutches of a megalomaniac. ${ }^{2}$ Although some evidence points to Riel's mental instability, he did not drive the Métis to war in 1885. To understand why the Métis and Canada fought in 1885, one has to look beyond Riel at three underlying causes of the conflict. One, the Resistance took place at the height of colonialism, as such it was a product of the Canadian and global imperialism prevalent during that time. Two, Canada never adequately dealt with Métis land claims from the 1870 Manitoba Act, which frustrated the Métis to the point of picking up arms in 1885. Three, drastic economic change and hardship had swept the west and the Métis had no help from the federal government, which increased Métis frustration. Together these factors caused the Northwest Resistance to erupt. Understanding them helps debunk the myth that Riel was the master architect behind 1885 .

Looking beyond Riel at the large picture of 1885 , we see that the Northwest Resistance was a result of Canadian and worldwide imperialism. To start, the 1880s were the height of the

\footnotetext{
${ }^{1}$ Adam Gaudry and Robert L. A Hancock, "Decolonizing Metis Pedagogies in Post-Secondary Settings," Canadian Journal of Native Education 35, 1 (2012): 8.

${ }^{2}$ Ibid.
} 
Age of Imperialism with 1885 as its absolute zenith. ${ }^{3}$ Historians Geoff Read and Todd Webb detail the aggressive geo-political maneuvering that occurred around the globe that year:

The year 1885 was an eventful one in the imperial world. In Germany, the Berlin Conference concluded its work of dividing Africa among the colonial powers; in Indochina, the French faced resistance in South Vietnam and Cambodia; in Afghanistan, Russia and the United Kingdom nearly went to war; in the Sudan, General Gordon's garrison in Khartoum was overrun by the Mahdists; in the United States, Josiah Strong published Our Country, declaring that it was the God-given duty of America to go forth and dominate the world. $^{4}$

Read and Webb note that underscoring all imperial aspirations during this epoch was the core belief in Social Darwinism which ranked human supremacy in phenotypic expression. ${ }^{5}$ According to Social Darwinism, Europeans were biologically superior to all other races and thus the rightful heirs to all global territory, while Indigenous people were understood to be childlike, unable to govern themselves, or make productive use of land. ${ }^{6}$ Ranked lower still were the miscegenetic or mixed race people-Métis - otherwise known as half-breeds, who were seen as deviant halves of two purer races. ${ }^{7}$ The idea that 'deviant half-breeds' could not control their behavior or manage their own lands can be found in a letter Sir John A. Macdonald, the Prime Minister of Canada, wrote to federal Finance Minister Sir John Rose on March 11, 1870: “It will never do to leave the future Government of that Country [the Northwest] at the mercy of these impulsive half-breeds... our object should be to get a Force into the Country [to rule it]." 8

W. P. R. Street, the head Scrip Commissioner for the Northwest Territories, reiterates Macdonald's Métis prejudice fifteen years later in an official memorandum dated March 26, 1885: "[T]he half-breeds were...dim [witted]...[with a] greater susceptibility to religious influences, and a general amelioration of the savage and ruthless instincts of the Indian race."9 According to historian Victoria Freeman, the racism shared by Macdonald and Street was

\footnotetext{
${ }^{3}$ Geoff Read and Todd Webb, "The Catholic Mahdi of the North West': Louis Riel and the Metis Resistance in Transatlantic and Imperial Context, 93, 2, (2012): 172.

${ }^{4}$ Ibid.

${ }^{5}$ Ibid., 174.

${ }^{6}$ Victoria Freeman, "Attitudes Toward "Miscegenation" in Canada, the United States, New Zealand, and Australia, 1860-1914," in Finding a Way to the Heart, ed. Valerie Korinek and Robin Jarvis Brownlie (Winnipeg: University of Manitoba Press, 2012): 203.

${ }^{7}$ Ibid., 203.

${ }^{8}$ QUEEN'S BENCH: WINNIPEG CENTRE. No. C. 81-01-01010. Manitoba Metis Federation Inc. vs. Attorney General of Canada and the Attorney General of Manitoba: Plaintiffs' Written Argument. Rosenbloom and Aldrigde. 2011. 46.

${ }^{9}$ W. P. R. Street, 42. "The Commission of 1885 to the North-West Territories," in The Canadian Historical Review, ed. H. H. Langton 25, 1 (1944): 42.
} 
commonplace in English-Canada after 1870 as most British protestants viewed the Métis as "violent...degenerate[s]" in need of conquering and subjugation. ${ }^{10}$ Read and Webb posit that because of these prejudices, the 1885 Resistance can be read as a Canadian expression of the "[racialized] themes that defined the late nineteenth-century imperial world, including AngloFranco rivalry, Protestant and Catholic antipathy, imperial expansion, anti-imperial resistance, and Social Darwinism." 11

Supporting Read's and Webb's claim is the fact that Canada and the United States, like every other imperial country in the world at that time, were vying for territory and were willing to exert force against Indigenous people to control land. American Imperialists believed in Manifest Destiny, which held that North America was rightfully theirs by divine decree, while Canadian Imperialists subscribed to the idea that British Protestantism/Anglo Saxony was the true master of the continent. ${ }^{12}$ Fueled by an ideology of supremacy, and trying to prove North America was theirs by God-given right, the U.S. had annihilated and removed whole tribes of western Indigenous people during the Indian Wars of the $1860-70 \mathrm{~s} .{ }^{13}$ The clearance of the American west had been made possible by the massive standing army the U.S. possessed after the Civil War ended in 1865, a portion of which had been redirected onto the plains to make way for Euro-settlement. ${ }^{14}$ Fortunately for Canada during this time, U.S. forces remained largely engaged in the southern Reconstruction effort where they could not be used to fulfill American aspirations of Manifest Destiny. ${ }^{15}$ However, in 1869 Dominion fortunes drastically changed when the U.S. completed the transcontinental Union Pacific Railway and then threatened to annex the Canadian Northwest with it. ${ }^{16}$ The Union Pacific had made Northwest annexation logistically possible and when Reconstruction ended in 1877 the threat became backed by a powerful U.S. army many times larger than Canada's. ${ }^{17}$ Macdonald clearly understood the looming threat the Americans posed, which is why after his 1879 re-election he began scrambling to build the Canadian transcontinental railway—regardless of economic cost. ${ }^{18}$ For

\footnotetext{
${ }^{10}$ Freeman, 204.

${ }^{11}$ Read and Webb, 174.

12 Joseph Kinsey Howard, Strange Empire: The Story of Louis Riel, (Toronto: Swan Publishing, 1965$), 17$.

${ }^{13}$ Ibid., 220.

${ }^{14}$ Ibid.

${ }^{15}$ Ibid.

${ }^{16}$ R. Douglas Francis, Richard Jones and Donald B. Smith, “A National Policy,” in Destinies: Canadian History Since Confederation, Sixth Edition, ed. Anne Williams (Toronto: Nelson Education Publishing, 2008 ):62.

${ }^{17}$ Webb and Read, 176

${ }^{18}$ Francis, Jones and Smith, 62.
} 
Macdonald, it was build the railway or lose the Northwest to the U.S. juggernaut. ${ }^{19}$ Historian D. N. Sprague underscores Macdonald's desperation by naming the project's only logical use at the time of its construction: "[The railway was] only sensible...from the standpoint of imperial defense... it was a vital 'Imperial link' [against the U.S.]",20

By the time Métis grievances came to the fore in 1885, the rail line was almost complete and it could finally be used for its originally intended purpose: to flex Canada's military might. ${ }^{21}$ According to Sprague, the U.S. threat coupled with the possibility of showcasing Canadian force via the transcontinental railway was one major reason why the federal government did nothing to appease the Métis prior to 1885: Macdonald needed the Indigenous uprising to prove to U.S. imperialists "that Canada could make a major military effort over great reaches of its own territory...[I]t [was] more symbolic than military...[it was a Canadian display] of state power."22 Macdonald knew that without the Canadian military victory of 1885 , the U.S. would have surely annexed the Northwest. He had to defeat the Métis or lose the Northwest. ${ }^{23}$ Moreover, the young Dominion also needed to prove it was a worthy member of the British Empire. What better foe than the "degenerate half-breeds" who were neither "fit to govern" the Northwest nor the "rightful masters of North America"? ${ }^{24}$ Webb and Read posit that because of the Social Darwinist attitudes of Protestant Canada and the looming threat of U.S. annexation, the Northwest Resistance was just another example of the "imperial adventuring" so prevalent during the Age of Imperialism. ${ }^{25}$ The Sudanese desert, the jungles of Vietnam, the Asante Gold Coast, South Africa, Egypt, Afghanistan, Saskatchewan, and other sites of resistance all occurred in and around 1885; all were overt displays of Euro-imperial power against people native to the land in question, and all were subjugations justified by the imperial logic of Social Darwinism. ${ }^{26}$ Furthermore, the acquisition of new lands and resources was the primary goal of all of these imperial endeavors-Canada's included. On a macro level then, it is quite clear that the Northwest Resistance was a product of the imperial times in which it was set, and not the

\footnotetext{
${ }^{19}$ Ibid.

${ }^{20}$ D. N. Sprague. Canada and the Metis, 1869-1885, (Waterloo: Wilfrid Laurier University Press, 1988 ): 142.

${ }^{21}$ Thomas Flanagan, Riel and the Rebellion: 1885 Reconsidered, Second Edition, (Toronto: University of Toronto Press, 2000): 4.

${ }^{22}$ Sprague, 2.

${ }^{23}$ Ibid.

${ }^{24}$ Read and Webb, 174.

${ }^{25}$ Ibid., 177.

${ }^{26}$ Read and Webb, 177.
} 
warmongering efforts of Riel. It is little wonder when we look past the "Riel the outside agitator" myth at the other root causes of the Northwest Resistance we see that land claims are the primary grievance of the Métis against Canada. It was, after all, the Canadian Imperialists' main point of concern as well.

Land claim recognition stands out alone as the single biggest complaint of the Métis between the years 1870-85; Canada's failure to adequately deal with the "land issue" is another reason why the Northwest Resistance erupted. Loss of land also shows Riel did not plan and execute the 1885 uprising, but rather joined an ongoing initiative organized by local Saskatchewan Métis who were fighting longstanding grievances. To begin, the Métis victory of 1869-70, the Red River Resistance, had forced the Dominion of Canada to admit Manitoba into Confederation with the signing of the Manitoba Act on May 12, 1870. ${ }^{27}$ The Act, which had infuriated Prime Minister Macdonald from the beginning, recognized Métis land claims and settlement by granting them an official homeland of their own - the province of Manitoba. ${ }^{28}$ Section 31 of the Manitoba Act clearly lays this out:

And whereas, it is expedient, towards the extinguishment of the Indian Title to the lands in the Province [Manitoba], to appropriate a portion of such ungranted lands, to the extent of one million four hundred thousand acres thereof, for the benefit of the families of the half-breed residents, it is hereby enacted, that, under regulations to be from time to time made by the Governor General in Council, the Lieutenant-Governor shall select such lots or tracts in such parts of the Province as he may deem expedient, to the extent aforesaid, and divide the same among the children of the half-breed heads of families residing in the Province at the time. $^{29}$

However, the Act's "half-breed" land claim stipulation was purposefully obstructed by Sir John A. Macdonald the moment the ink dried. ${ }^{30}$ Macdonald's real desire to sabotage Métis land claims in Manitoba can be heard in an official letter he wrote to John Rose dated February 23, 1870: "These impulsive half-breeds have got spoiled by their émeute [Red River Resistance] and must be kept down by a strong hand until they are swamped by the influx of settlers." ${ }^{31}$ Macdonald, through the Ministry of the Interior, went about "swamping" the "half-breeds" by confirming Métis land scrip at a snail's pace whilst promoting aggressive Canadian land speculation across

\footnotetext{
${ }^{27}$ Manitoba Act (1-36 Victoria, c. 3 (Canada) - assented to on May 12, 1870).

${ }^{28}$ Ibid.

${ }^{29}$ Manitoba Act. 31 Victoria, c. 3.

${ }^{30}$ Flanagan, 9.

${ }^{31}$ PAC, Macdonald Papers, Incoming Correspondence, p. 40208, Draft Order in Council for Uniting Rupert's Land and the North-Western territories to the Dominion of Canada. Macdonald to Rose, 1870.
} 
Manitoba. ${ }^{32}$ Land scrip was the extinguishment of Métis land title by awarding a certificate redeemable for a 160 or 240 acre allotment of land or money - cash was granted immediately, land confirmation often took years. ${ }^{33}$ Scholar Jennifer Reid details the "swamping" process by showing how rapidly Winnipeg was enveloped by new Canadian settlers:

[T]he Macdonald's administration did nothing to confirm land claims of existing [Métis]. Rather...new immigration was actively promoted and the claims of new [Canadian] settlers recognized rapidly...A policy for [Métis land] distribution took more than two years to be put into effect, during which time land speculators were accumulating land around Winnipeg at a rapid pace-by 1872, forty thousand acres had been purchased. ${ }^{34}$

By the mid-1870s, inaction from Ottawa combined with bad harvests, epidemic disease, and the disappearance of the buffalo from Manitoba forced the waiting Métis to sell their land scrip for cash so they would not starve. ${ }^{35}$ Historian J. M. Bumsted notes that the Manitoba legislature saw what was happening and tried to stop the coercive practice by passing a bill "'to restrict the sale of Métis land scrip for cash' but was told by Ottawa that 'such legislation would be unconstitutional." " 36 Purposefully denied protection from Ottawa, by 1880 the Métis were unwanted strangers in their own province, "swamped," just as Macdonald had wanted, by the "massive influx of settlers." ${ }^{, 37}$ Disgruntled and betrayed, the majority of Métis moved west to northern Saskatchewan, but here again they were faced with the Dominion government's failure to recognize their land claims.

Canada's inaction in dealing with the Métis land claims continued in Saskatchewan along the same lines as events in Manitoba since 1870 and this indifference can be read as another cause of the 1885 Northwest Resistance. The trouble all started in 1883 when government surveyors arrived in the Batoche region of northern Saskatchewan to introduce the square lot land system employed elsewhere in the country. ${ }^{38}$ However, and contrary to the square lots system, the Métis had already settled the region according to their own traditional river lot system, which divided property back from the banks of the North Saskatchewan River in long

\footnotetext{
${ }^{32}$ J. M. Bumsted, Louis Riel Vs. Canada: The Making of a Rebel, (Winnipeg: Great Plains Publications, 2001): 243.

${ }^{33}$ Camie Augustus, Our Legacy: Ka-ki-pe-isi-nakatamakawiyahk T a bet a dene dahidli, http://scaa.sk.ca/ourlegacy/exhibit_scrip (Date Accessed Nov. 24. 2013).

${ }^{34}$ Jennifer Reid, Louis Riel and the Creation of Modern Canada: Mythic Discourse and the Postcolonial State, (Winnipeg: University of Winnipeg Press, 2012): 16.

${ }^{35}$ Bumsted, 243.

${ }^{36}$ Ibid.

${ }^{37}$ Flanagan, 9.

${ }^{38}$ Bumsted, 244.
} 
narrow strips of land. ${ }^{39}$ As well, the presence of the surveyors triggered strong feelings of mistrust and fear that had their roots in the land betrayal of 1870 and many Métis believed the land-grab that had transpired in Manitoba was about to happen again in Saskatchewan. ${ }^{40}$ Moreover, according to Bumsted, the surveyors knew how uneasy the Métis felt about their presence in Batoche but made no effort to be hospitable or "mesh" the opposing land systems together. ${ }^{41}$ Several times the concerned Métis approached George Duck, the Dominion Lands Agent in Prince Albert, trying to attain legal title for their river lots but their requests were denied and they were told: "the land was not open [to them]." ${ }^{42}$ In the eyes of government officials, the Métis were "illegal migrant squatters" who had no right to occupy land in Saskatchewan let alone complain about the square lot system or request land allotments there. ${ }^{43}$ The Dominion took an ardent stance against Métis land claims because they thought that the Métis, like all other Indigenous people in Saskatchewan in 1885, had had their land title extinguished with the signing of Treaty Six in $1876 .{ }^{44}$ As such, between the years 1883-84 many Métis petitions for land patents were sent to Ottawa and almost all were rejected. Sprague notes: "out of the more than 250 Métis demanding land patents less than 10 were considered legally entitled to what they claimed." ${ }^{45}$ In June 1884, Chief Factor of Fort Carlton Lawrence Clark details that the Métis settlement of St. Laurent, where most of the land patents originated, had already "reach[ed] a point of crisis [and that] repressive measures were needed [to control the region]. ${ }^{46}$ Six months later, on December 16, 1884, the Métis, who had been pushed out of Manitoba and who were now being shut out of Saskatchewan, had sent their last land petition to Ottawa for which they received no response. ${ }^{47} \mathrm{By}$ not responding to this last petition the Macdonald administration had, by way of callous indifference, goaded the fearful Métis to take up arms to protect their property. ${ }^{48}$ Only by positive action from Ottawa during the winter of 1884-85 could the Resistance have been avoided because the will to fight had essentially been

\footnotetext{
${ }^{39} \mathrm{Ibid}$.

${ }^{40}$ Ibid.

${ }^{41}$ Bumsted, 244

${ }^{42}$ Sprague, 159.

${ }^{43}$ Ibid., 158.

${ }^{44}$ Street, 43.

${ }^{45}$ Sprague, 162.

${ }^{46}$ Ibid.

${ }^{47}$ Lawrence J. Barkwell, Veterans and Families of the Northwest Resistance, (Saskatoon: Gabriel Dumont Institute, 2011): 27-29.

${ }^{48}$ Barkwell, 27-29.
} 
solidified in a secret meeting at Abraham Montour's house on March 22, 1884, nine months before the last petition was sent. ${ }^{49}$ It was also the day Gabriel Dumont, Napoleon Nault, and thirteen other Métis leaders decided to send for Riel in Montana. ${ }^{50}$ March 22, 1884, was roughly three months before Riel returned to Canada on July 4, 1884, and twelve months before the opening shots of the Resistance were fired at Duck Lake on March 26, $1885 .{ }^{51}$ With these facts in mind it is very hard to see how Riel the "megalomaniac" could have planned and executed the Northwest Resistance. However, for the final debunking of the "Riel the master architect" myth we must now turn to the belly of the Métis and see how hunger caused by hardship and economic change finally spurred the Métis to rise up in 1885.

The years 1880-84 were very hard for the Métis of northern Saskatchewan in terms of hardship and economic change, and Canada's failure to provide aid during this extreme crisis is another cause of the Northwest Resistance that shows Riel did not orchestrate 1885. In a July 25, 1884, article in the Winnipeg Sun, Colonel Houghton reveals just how bad living conditions had become for the Métis of Batoche:

Being asked about the discontent among the Half-Breeds, the Colonel stated that they were really in a bad way. Consequent upon the great drought, which prevails all summer, the crops all along the Half-Breed settlement are almost an entire failure and starvation stares the poor creatures in the face...Col. Houghton did not have very much conversations [sic] with the settlers, but those [with] whom he did speak informed him of the bad state of affairs existing. They have not been able to procure patents for their lands...Col. Houghton believes if they had their patents they would be appeased, to a certain extent, as by the sale of a portion of their land they could keep the wolf from the door [starvation]. ${ }^{52}$

The famine of 1884 may have been alarming to Colonel Houghton, but it was by no means an unknown or isolated phenomenon. ${ }^{53}$ The early 1880 s in Saskatchewan were characterized by successive crop failures, numerous droughts, the disappearance of the buffalo, and economic depression. ${ }^{54}$ The Métis who resided there had been slowly starving to death for over half a decade. ${ }^{55}$ Thomas Flanagan shows how low rainfall coupled with the disappearance of the buffalo in 1878 had doomed the Métis to starvation by way of agricultural conditions:

\footnotetext{
49 Ibid.

${ }^{50}$ Ibid.

51 Ibid.

${ }^{52}$ Winnipeg Sun, July 25, 1884. Cited in the House of Commons Debates, CSP, 1885: 3087.

53 Reid, 17.

54 Ibid.

${ }^{5}$ Ibid.
} 
The buffalo vanished after 1878, adversely affecting several lines of business in which the Métis had made their living: buffalo hunting, trading with the Indians for pemmican and robes, and transporting these [needed] goods to market[s]...Deprived of their income from traditional occupations the Métis had to rely on [poor] agriculture. ${ }^{56}$

The final nail in the Métis sustenance coffin may have been the worldwide depression of 1883, which drove grain prices so low that any successful farmer among them, unable to turn a profit or sell their crops, abandoned wheat farming altogether by late fall of that year. ${ }^{57}$ By midsummer 1884, they, along with all the other Métis of Batoche, were destitute and starving, pleading with the government for relief. ${ }^{58}$ Underscoring all this environmental hardship and misfortune had been the fifteen-year exodus from Manitoba that had drained the financial reserves of the Métis emigrants to Saskatchewan. ${ }^{59}$ With the buffalo gone, when the droughts of the early 1880s hit, the Métis had no failsafe to guard against crop failure and starvation as did the more established Euro-settlers, which is why the former revolted and the latter did not. ${ }^{60}$ Additionally, the lack of a financial backup, nonexistent because of the imposed reserve system, is also why the starving First Nations people in northern Saskatchewan had decided to rise up alongside the Métis in $1885 .{ }^{61}$ Jennifer Reid illustrates just how dire things had become in Saskatchewan and how neglectful the Dominion had been during the famine of 1884: "[P]eople throughout the North-West were suffering from extreme starvation. The Federal government did virtually nothing to address [it]. ${ }^{, 62}$ Sprague notes that during this time the callous government indifference had created great unrest among the Métis and First Nations people and many were "on the point of taking extreme action." 63

Creating even greater unrest in northern Saskatchewan was the economic change that came with the Canadian Pacific Railway, and this last factor, which exacerbated the Métis hardships of the time, can be seen as the final cause of the 1885 Resistance. Initially, The CPR was supposed to have taken a northerly route through Battleford, Saskatchewan, which would have brought the Métis of Batoche great employment opportunities, increased industry, local

\footnotetext{
${ }^{56}$ Flanagan, 85.

${ }^{57}$ Ibid.

${ }^{58}$ Ibid.

${ }^{59}$ Reid, 17.

${ }^{60}$ Reid, 16.

${ }^{61}$ Ibid., 17.

${ }^{62}$ Ibid.

${ }^{63}$ Sprague, 162.
} 
economic growth, and a plethora of rail line building contracts. ${ }^{64}$ However, this did not happen as the CPR, between the years 1881-85, had been redirected south through Regina effectively destroying any prospects that would have come to the Métis via the northern route. ${ }^{65}$ Furthermore, Sprague details the negative economic shift that occurred in the north once the southern CPR track became fully operational in 1885: “"[H]alf breeds' in the [north] District of Saskatchewan were losing freighting employment to the railway and steamboats, they were becoming poorer and poorer." 66 Lieutenant Governor of the Northwest Territories Edgar Dewdney in a letter to Prime Minister Macdonald dated 14 June, 1884, describes how the Hudson's Bay Company had drastically cut "both volume and rate of pay" for Métis freighters after the railway was operational which caused "the half-breeds to protest violently [against the loss of their livelihoods]. ${ }^{, 67}$ Flanagan points out that those Métis who received lower pay and a reduced freighting volume from the HBC had been the lucky ones as most went completely without work after the railroad "destroyed the traditional Métis cart and boat brigade [economies in Saskatchewan]."68

Freighting by boat and cart had been how many Métis had made a living for a century and a half and when this employment disappeared, they simply possessed no other means to put food on the table. With no crops, no buffalo, no reserve money, no economy, and no hope for relief, the Métis of Batoche had no options left. It was literally fight to get the attention of the distant government or starve to death in the face of its indifference. The hardship and economic changes of the 1880s were the final causes of the Northwest Resistance and unless Riel diverted and built the transcontinental railway, controlled precipitation levels during the early 1880s, or destroyed the vast buffalo herds of the great plains it is impossible to continue believing that he was the "master architect" who manipulated the Métis to fight against Canada in 1885.

In conclusion, the historiographical myth that Riel the master puppeteer manipulated the Métis to fight against the Dominion of Canada in 1885 is simply untrue. A new historical understanding of the Northwest Resistance comes when one looks past Riel at the three underlying causes of the conflict. One, the struggle happened in 1885 at the height of imperialism and was a product of that time. Two, land claims were not properly dealt with by

\footnotetext{
${ }^{64}$ Reid, 17.

65 Ibid.

${ }^{66}$ Sprague, 162.

${ }^{67}$ PAC, Macdonald Papers, Incoming Correspondence, pp. 42244-42250, Dewdney to Macdonald, 14 June, 1884.

${ }^{68}$ Flanagan, 85.
} 
Canada from the 1870 Manitoba Act up to 1885, which goaded the Métis to arms. Three, economic change and hardship hit the Métis hard in the 1880s and with no help from the federal government, the Northwest Resistance became the Métis' last desperate cry for relief. When put in the proper context, it becomes very apparent that Riel, although he played a key part, could not have been the central motor of the Northwest Resistance, which begs two questions. Why would he be painted as a subversive incendiary? Who benefited from such a narrative? In answering these two questions I do feel that the man who has been painted as a "rabble-rouser" will be fully vindicated and that blame for the conflict will fall, at long last, onto the apparatus of colonialism where it is truly due. 


\section{Bibliography}

Augustus, Camie. Our Legacy: Ka-ki-pe-isi-nakatamakawiyahk T a bet a dene dahidli. http://scaa.sk.ca/ourlegacy/exhibit_scrip (Date Accessed: Nov. 24. 2013).

Barkwell, Lawrence J. Veterans and Families of the Northwest Resistance. Saskatoon: Gabriel Dumont Institute, 2011.

Bumsted, J. M. Louis Riel Vs. Canada: The Making of a Rebel. Winnipeg: Great Plains Publications, 2001.

Flanagan, Thomas. Riel and the Rebellion: 1885 Reconsidered. Second Edition. Toronto: University of Toronto Press, 2000.

Francis, R. Douglas, Jones, Richard and Donald B. Smith, “A National Policy,” in Destinies: Canadian History Since Confederation, Sixth Edition. Ed. Anne Williams Toronto: Nelson Education Publishing, 2008.

Freeman, Victoria. "Attitudes Toward "Miscegenation" in Canada, the United States, New Zealand, and Australia, 1860-1914," in Finding a Way to the Heart. Ed. Valerie Korinek and Robin Jarvis Brownlie. Winnipeg: University of Manitoba Press, 2012.

Gaudry, Adam and Robert L. A Hancock, "Decolonizing Métis Pedagogies in PostSecondary Settings.” Canadian Journal of Native Education 35, 1 (2012): 7-22.

Howard, Joseph Kinsey. Strange Empire: The Story of Louis Riel. Toronto: Swan Publishing, 1965.

Manitoba Act (1-36 Victoria, c. 3 (Canada) - assented to on May 12, 1870).

PAC, Macdonald Papers, Incoming Correspondence, pp. 42244-42250. Dewdney to Macdonald. 14 June, 1884.

PAC, Macdonald Papers, Incoming Correspondence, pp. 40208. Draft Order in Council for Uniting Rupert's Land and the North-Western territories to the Dominion of Canada. Macdonald to Rose. 1870.

QUEEN'S BENCH: WINNIPEG CENTRE. No. C. 81-01-01010. Manitoba Métis Federation Inc. and others suing in their own behalf of all other descendants of Métis Person entitled to land and other rights Section 21 and 32 of the MANITOBA ACT, 1870. \& Congress of Aboriginal Peoples vs. Attorney General of Canada and the Attorney General of Manitoba: Plaintiffs' Written Argument. Rosenbloom and Aldrigde. 2011.

Read, Geoff and Todd Webb. "The Catholic Mahdi of the North West': Louis Riel and the Métis Resistance in Transatlantic and Imperial Context." In the Canadian Historical Review 93, 2 (2012): 171-195 
Reid, Jennifer. Louis Riel and the Creation of Modern Canada: Mythic Discourse and the Postcolonial State. Winnipeg: University of Winnipeg Press, 2012.

Sprague, D. N. Canada and the Métis, 1869-1885. Waterloo: Wilfrid Laurier University Press, 1988.

Street, W. P. R. "The Commission of 1885 to the North-West Territories," in The Canadian Historical Review. Ed. H. H. Langton. 25, 1 (1944): 38-53.

Winnipeg Sun, July 25, 1884. Cited in the House of Commons Debates. CSP. 1885: 3087. 